\title{
The Pattern of Arrangements and Distributions of the Superior Mesenteric Artery in a Nigerian Population
}

\author{
Patrón de Disposición y Distribución de la Arteria \\ Mesentérica Superior en la Población de Nigeria
}

\author{
Anozeng Oyono Igiri; Moses Bassey Ekong; Geoffrey Okechukwu Egemba \& Olaitan Ruth Asuquo
}

\begin{abstract}
IGIRI, A. O.; EKONG, M. B.; EGEMBA, G. O. \& ASUQUO, R. O. The pattern of arrangements and distributions of the superior mesenteric artery in a Nigerian population. Int. J. Morphol., 28(1):33-36, 2010.

SUMMARY: This study was to ascertain the pattern of arrangements and distributions of the superior mesenteric artery (SMA) in a Nigerian population. Seventy-five cadavers certified as Nigerians were obtained from the dissecting room of the Department of Anatomy, University of Calabar after ethical approval from the Institution's Ethics Committee. Their abdomens and their contents were excise to expose the vessels. Based on the pattern of arrangements of the SMA, the cadavers were grouped into three (A, B, and C). Group A had 45 cadavers and this constituted $60 \%$ which were similar to the commonly documented patterns. Groups B and C had 20 and 10 cadavers respectively constituting $26.7 \%$ and $13.3 \%$ pattern of arrangement, some of which have not been documented before. In conclusion these peculiar patterns in this population are to be noted in surgical procedure, since damage to these variant vessels may result in severe haemorrhage that may lead to other complications.
\end{abstract}

KEY WORDS: Superior mesenteric artery; Variation; Nigeria.

\section{INTRODUCTION}

The superior mesenteric artery (SMA) supplies the midgut (Moore \& Persaud, 2004; Sinnatamby, 2006). This is the portion of the digestive tract extending from the duodenum at the opening of the bile duct to the junction between the right two-third and left one-third of the transverse colon (Moore \& Dalley, 2006; Sinnatamby). This midgut derivatives includes; the small intestine including the duodenum inferior to the opening of the bile duct; the caecum, appendix vermiformis, ascending colon and the right two-third of the transverse colon (Moore \& Persaud).

The SMA which supplies this portion of the gut with oxygen-rich blood arises from the anterior surface of the abdominal aorta one centimeter below the ceoliac trunk at the level of the lower border of L1 vertebra. It is directed steeply downwards entering the upper end of the mesentery of the small intestine down to the right along the roof of the mesentery to the ileocaecal junction (Sinnatamby).
The artery gives off several branches which include; the inferior pancreaticoduodenal artery from the posterior surface, jejunal and ileal branches from the left surface, and ileocolic, right colic and middle colic branches from right surface (Moore \& Dalley; Sinnatamby).

Variations in the branching and distributions of the SMA and other vessels are common (Benton \& Cotter, 1963; Koizumi \& Horiguchi, 1990: Nelson et al., 2005; Sato et al., 2007). In about fifty percent (50\%) of cases, the marginal artery which is a result of the anastomosis of the branches of the SMA and inferior mesenteric artery (IMA) may be discontinuous because of the failure of the anastomosis between the left and the right colic arteries (Basmajian, 1980). The right colic artery may originate from the middle colic or ileocolic arteries, and a large branch, the Arc of Rioland, may occasionally connect the stem of the SMA with the left colic artery on the posterior abdominal wall (Steward \& Rankin, 
1933; Sonneland et al., 1958; Lange et al., 2007). There have been reports of cases where the right and middle colic arteries were absent leaving the entire supply of the colon to the IMA.

In other variations, the hepatic or accessory hepatic and cystic arteries have been reported to arise from the SMA either alone or together (Amonoo-Kuofi et al., 1994; Jones \& Hardy, 2001; Bergman et al., 1988). In rare cases the IMA has also been reported to arise from the SMA either alone or along with the hepatic artery (Kitamura et al., 1987; Osawa et al., 2004; Yi et al., 2008). The right gastroepiploic artery has also been reported to arise from the SMA (Sakamoto $e t$ al., 1999). In other cases, branches' hitherto arising from the SMA has been reported to arise from the celiac trunk or from a coeliacomesenteric trunk (Yíldílrím et al., 2004; Çiçekcibas, i et al., 2005; Katagiri et al., 2006).

Most of these variations where found in subjects in other parts of the world other than Nigerians. Thus, this study was to find out the pattern and prevalence of variations of the SMA involving a Nigerian population.

\section{MATERIAL AND METHOD}

Seventy-five adult male cadavers were used for this study. They were obtained from the Gross Anatomy Dissecting room of the Department of Anatomy of the University of Calabar, Calabar, Nigeria, after ethical approval from the Institution's Ethics Committee. The cadavers were certified as Negroes and Nigerians by virtue of their skin colour, hair texture and personal information obtained from their records in the department.

The cadavers were embalmed for six months, after which their anterior abdominal walls were incised and reflected following the method of Cunninghams (Romanes, 1996). The peritoneum and the visceri were carefully separated and cleaned from the field of view. Each of their SMAs was then traced proximally and distally after injection of red ink near its origin. This was done with the root ligated to prevent the flow of the ink into the aorta. Observations were grouped according to the pattern of arrangements and distributions of the arteries into A, B and C and their numbers were recorded and prevalence calculated.

\section{RESULTS}

Group A: These were made up of 45 cadavers and constituted 60\% of the cadavers studied (Table I and Fig.
1). The pattern of arrangement was similar to already documented patterns: the jejunal arteries were two in number (range 1-2) and the ileal arteries were seven in number (range 5-15). They all arose from the left side of the SMA;

The middle colic artery arose before the SMA on the right side and ran forward in the transverse mesocolon to supply the transverse colon, dividing into two branches; The ileocolic artery arose on the right side of the SMA and passed downwards, dividing into a superior branch which anastomoses with the descending branch of the right colic artery, and an inferior branch that anastomosed with the end of the SMA.

The right colic artery divided into two branches, ascending and descending near its origin. It often arise as a branch of the ileocolic artery (Moore \& Dalley), the inferior pancreaticoduodenal artery passed to the right as a single branch along the upper border of the duodenum and the head of the pancreas.

Group B: These were made up of 20 cadavers which constituted $26.7 \%$ of the cadavers studied (Table I and Fig. 2). Only the peculiar patterns are reported: The jejunal arteries were made up of three branches; the ileocolic artery gave rise to the appendicular artery directly. There was no ileal branch;

The terminal part of the ileum was supplied by a branch from the main trunk of the SMA; the middle colic artery arose from the SMA after the branches of the jejunal arteries, and the inferior pancreaticoduodenal artery arose from the aorta under the root of the SMA.

Group C: These were made up of 10 cadavers and constituted $13.3 \%$ of the cadavers studied (Table 1 and Fig. 3). Only the peculiar patterns are reported: the jejunal artery had only one branch which was a large artery. Several smaller branches arose from this to supply the jejunum; the ileal arteries had numerous small sized branches; the middle colic artery gave rise at its origin to an accessory left colic artery; the right colic artery anastomosed directly with the middle colic artery; the right colic artery did not form the marginal artery with the ileocolic artery.

Table I. The number of cadavers per group and their prevalence.

\begin{tabular}{ccc}
\hline Groups & Number of & Prevalence (\%) \\
\hline Group A & 45 & 60 \\
Group B & 20 & 26.7 \\
Group C & 10 & 13.3 \\
Total & 75 & 100 \\
\hline
\end{tabular}




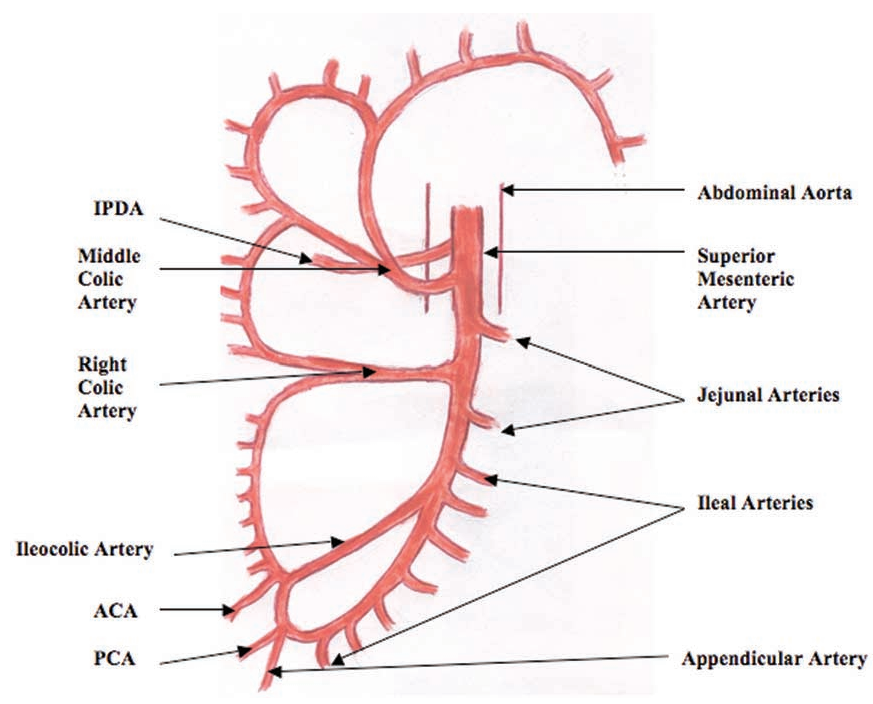

Fig. 1. Group A with 45 cadavers having a prevalence of $60 \%$. ACA. Anterior caecal artery; IPDA. Inferior pancreaticoduodenal artery; PCA. Posterior colic artery.

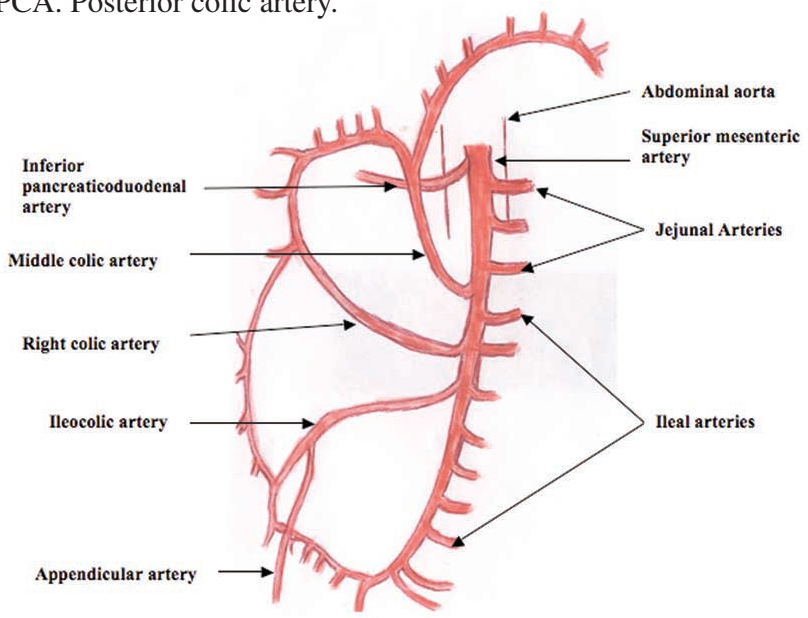

Fig. 2. Group B with 10 cadavers having a prevalence of $26.7 \%$.

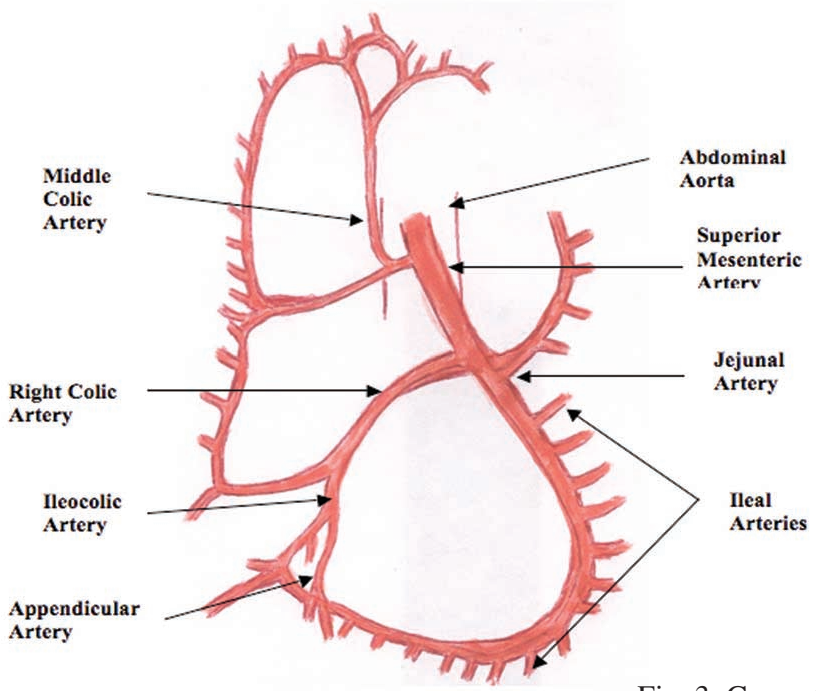

Fig. 3. Group C with 10 cadavers having a prevalence of $13.3 \%$.

\section{DISCUSSION}

The pattern of arrangement and prevalence of the distribution of the SMA in a Nigerian population was carried out. Group A presented the most commonly documented pattern of arrangement. The prevalence in this study was sixty percent $(60 \%)$ which was the highest. This is in line with previous reports (Moore \& Dalley; Sinnatamby)

Groups B and C presented variations with prevalence of $26.7 \%$ and $13.3 \%$ respectively with some being peculiar to this population. The right colic artery was found to originate from the ileocolic artery which is the major branch of the SMA. This observation has been documented (Sonneland et al.). They stated that $23.8 \%$ of 600 cases studied had their right colic artery arising from either the ileocolic artery or the middle colic artery.

In all the cases, the jejunal and ileal arteries were made up of 7-12 and 1-3 branches respectively. This is at variance to previous works were the jejunal and ileal arteries were composed of 8-13 and 4-7 arteries respectively (Basmajian).

The marginal arteries of the right colic and ileocolic arteries were not continuous in group $\mathrm{C}$. This is similar to earlier workers who reported that the marginal artery may be discontinuous due to the ileocolic artery failing to anastomose with the right colic artery, and that the right colic artery very commonly may originate from the middle colic or ileocolic arteries (Steward \& Rankin; Michels et al., 1963).

In conclusion, the pattern of arrangement of the SMA in this Nigerian population may be divided into three groups, with the commonly occurring pattern present in $60 \%$ of the population, and other variations occurring in about $27 \%$ and $13 \%$ of the populations. Nigeria is a country with diverse ethnic groups, but there is no outstanding variation in body proportions documented. Thus, we may use this population to state that these variations reported should be noted in surgical procedure of Nigerians, since damage to these variant vessels may result in severe haemorrhage that may lead to other complications. Thus these variations are important in clinical anatomy for surgical practice. 
IGIRI, A. O.; EKONG, M. B.; EGEMBA, G. O. \& ASUQUO, R. O. Patrón de disposición y distribución de la arteria mesentérica superior en la población de Nigeria. Int. J. Morphol., 28(1):33-36, 2010.

RESUMEN: Este estudio consistió en determinar el patrón de disposición y distribución de la arteria mesentérica superior (AMS) en una población de Nigeria. Setenta y cinco cadáveres certificados como nigerianos se obtuvieron de la sala de disección del Departamento de Anatomía de la Universidad de Calabar, después de la aprobación ética del Comité Ético de la Institución. Su abdomen y sus contenidos fueron disecados para exponer los vasos. Basado en el modelo de disposición de la AMS, los cadáveres fueron agrupados en tres grupos (A, B y C). Grupo A tuvo 45 cadáveres y estos constituyeron el $60 \%$ los cuales fueron similares a los patrones comúnmente documentados. Los Grupos B y C con 20 y 10 cadáveres respectivamente, constituyeron el 26,7\% y 13,3\% del patrón de disposición, algunos de los cuales no se han documentado antes. En conclusión, estos patrones peculiares en esta población han sido observados en procedimientos quirúrgicos, ya que el daño a estas variantes de vasos pueden resultar en hemorragias graves que pueden conducir a otras complicaciones.

\section{PALABRAS CLAVE: Arteria mesentérica superior; Variación; Nigeria.}

\section{REFERENCES}

Amonoo-Kuofi, H. S.; el-Badawi, M. G. Y. \& el-Naggar, M. E. Anamolous origins of colic arteries. Clin. Anat., 8(4):288-93, 1994.

Basmajian, J. V. Grant's Method of Anatomy. 10 ${ }^{\text {th }}$ Ed. Baltimore, William \& Wilkins, 1980.

Benton, R. S. \& Cotter, W. B. A hitherto undocumented variation of the inferior mesenteric artery in man. Anat. Rec., 145:171-3, 1963.

Bergman, R. A.; Thompson, S. A.; Afifi, A. K. \& Saadeh, F. A. Compendium of Human Anatomic Variations. Baltimore-Munich, Urban \& Schwarzenberg, 1988.

Çiçekcibas,i, A. E.; Uysal, I. L.; Ss eker, M.; Tuncer, I.; Büyükmumcu, M. \& Salbacak, A. A rare variation of the coeliac trunk. Ann. Anat., 187(4):378-91, 2005.

Jones, R. M. \& Hardy, K. J. The hepatic artery: a reminder of surgical anatomy. J. R. Coll. Surg. Edinb., 46(3):168-70, 2001.

Katagiri, H.; Ichimura, K. \& Sakai, T. A case of celiacomesenteric trunk with some other arterial anomalies in a Japanese woman. Anat. Sci. Int., 82(1):53-8, 2006.

Kitamura, S.; Nishiguchi, T.; Sakai, A. \& Kumamoto, K. Rare case of the inferior mesenteric artery arising from the superior mesenteric artery. Anat. Rec., 217(1):99-102, 1987.

Koizumi, M. \& Horiguchi, M. Accessory arteries supplying the human transverse colon. Act. Anat., 137:246-51, 1990.

Lange, J. F.; Komen, N.; Akkerman, G.; Nout, E.; Horstmanshoff, H.; Schlesinger, F.; Bonjer, J. \& Kleinrensink, G. Riolan's arch: confusing, misnomer, and obsolete. A literature survey of the connection(s) between the superior and inferior mesenteric arteries. Am. J. Surg., 193(6):742-8, 2007.

Michels, N. A.; Siddharth, P.; Kornblith, P. L. \& Parke, W. W. The variant blood supply to the small and large intestines; its import in regional resections. J. Int. Coll. Surg., 39:127-70, 1963.

Moore, K. L. \& Dalley, A. F. Clinically Oriented Anatomy. $5^{\text {th }}$ Ed. Baltimore, Williams \& Wilkin, 2006.

Moore, K. L. \& Persaud, T. V. N. Clinically Oriented Embryology. $4^{\text {th }}$ Ed. New Delhi, Saunders-Elsevier, 2004.
Nelson, T. M.; Pollak, R.; Jonasson, O. \& Abcarian, H. Anatomic variants of the celiac, superior mesenteric, and inferior mesenteric arteries and their clinical relevance. Clin. Anat., 1(2):75-91, 2005.

Osawa, T.; Feng, X.; Sasaki, N.; Nagato, S.; Matsumoto, Y.; Onodera, M.; Nara, E.; Fujimura, A. \& Nozaka, Y. Rare case of the inferior mesenteric artery and the common hepatic artery arising from the superior mesenteric artery. Clin. Anat., 17(6):518-21, 2004.

Romanes, G. J. Cunningham's Manual of Practical Anatomy. Thorax and Abdomen. London, Oxford University Press, 1996. V.2.

Sakamoto, H.; Akita, K. \& Sato, T. An anomalous right gastroepiploic artery arising from the superior mesenteric artery. Surg. Radiol. Anat., 21(4):283-6, 1999.

Sato, O.; Matsumoto, I. \& Kondoh, K. Middle mesenteric artery encountered during abdominal aortic aneurysm surgery. Jpn. J. Vasc. Surg., 16(7):799-801, 2007.

Sinnatamby, C. S. Last's Anatomy: Regional and Applied. $11^{\text {th }}$ Ed. Edinburgh, Elsevier/Churchill Livingstone-Elsevier, 2006.

Sonneland, J.; Anson, B. J. \& Beaton, L. E. Surgical anatomy of the arterial supply to the colon from the superior mesenteric artery based upon a study of 600 specimens. Surg. Gynecol. Obstet., 106:385-98, 1958.

Steward, J. A. \& Rankin, F. W. Blood supply of the large intestines: its surgical consideration. Arch. Surg., 26:843-91, 1933.

Yi, S.; Li, J.; Terayama, H.; Naito, M.; Iimura, A. \& Itoh, M. A rare case of inferior mesenteric artery arising from the superior mesenteric artery, with a review of the review of the literature. Surg. Radiol. Anat., 30(2):159-65, 2008.

Yíldílrím, M.; Çelik, H. H.; Yíldíz, Z.; Tatar, I. \& Aldur, M. M. The middle colic artery originating from the coeliac trunk. Folia Morphol., 63(3):363-5, 2004.

\section{Correspondence to:}

M. B. Ekong

Department of Anatomy

Faculty of Basic Medical Sciences

University of Uyo, Uyo

NIGERIA

Received: 21-03-2009

Accepted: 25-08-2009 